\title{
Pesticide Residue Flux from Rainwater into Lake Nakanuma in the Rainy Season
}

\author{
Seiichi Nohara, Takayuki Hanazato and Toshio Iwakuma
}

\begin{abstract}
Pesticide residues in rainwater were investigated for the estimation of pesticide flux into a lake in Ibaraki Prefecture during the 1990 rainy season. The maximum concentration of oxiadiazon in the rainwater was $4.2 \mu \mathrm{g} \mathrm{l}^{-1}$. The maximum concentrations of fenobucarb, fenitrothion and edifenphos in the rainwater were $0.58,0.53$ and $0.36 \mu \mathrm{g} \mathrm{l}^{-1}$, respectively. The annual ratio of fenitrothion redeposition by rainfall was estimated at $1.5 \%$ of the total shipping amount in Ibaraki Prefecture. There was no significant difference between redepositions of pesticides by rainfall and shipping amounts in the prefecture ( $\alpha=$ 0.05 ). Pesticide residues in lake water were investigated in Lake Nakanuma, Ibaraki Prefecture, from March to December 1990. The concentrations of molinate, simetryn, iprobenfos, and thiobencarb in irrigation canal water were in the high range $\left(>1.2 \mu \mathrm{g} \mathrm{l}^{-1}\right)$. The concentrations of diazinon, malathion, and fenthion in the water were at a lower level $\left(<0.2 \mu \mathrm{g} \mathrm{l}^{-1}\right)$. The maximum concentration of simetryn in the lake was $0.91 \mu \mathrm{g} \mathrm{l}^{-1}$. Except for chlornitrofen, the maximum concentration of pesticide in the lake $\left(<1.0 \mu \mathrm{g} \mathrm{l}^{-1}\right)$ was about one-tenths in that of irrigation canals. The amount of pesticide from rainfall was a major factor from the viewpoint of estimating the environmental viability of the lake.
\end{abstract}

Key words : environmental fate, Lake Nakanuma, pesticide, rainfall

\section{INTRODUCTION}

Pesticides applied to rice paddies and golf courses for pest and/or weed control contaminate aquatic ecosystems. These pesticide residues have been detected in rivers surrounded by paddy fields in Japan (SuzukI, 1982; IMANAKA et al., 1985 ; MARU, 1985 ; FuKUSHIMA, 1991 ; HatAKEYAMA et al., 1991 ; TAKAMURA et al., 1991 ; NUMABE et al., 1992 ; IWAKUMA et al., 1993 ; NOHARA and IWAKUMA, 1996a). Water which is used over and over for irrigation finally enters lakes. However, little is known about the longterm effects and types of pesticide residues of in lake water (IMANAKA $e t$ al., 1985 ; ShIRAISHI et al., 1988 ; NohaRa and IWAKUMA, 1996a, b). Lakes are a very important sources of drinking water, as well as being used for fisheries, and providing a habitat for aquatic organisms. Some pesticides 
escape as vapor from agriculture fields and golf courses (GRover, 1974; OKUMURA, 1991 ; FushiWaKI et al., 1993 ; HaYaKaWa et al., 1996). However, some level of vaporized pesticides seem to return to the ground with rainwater (TARRANT and TATTON, 1968 ; VISWESWARIAH et al., 1975 ; UNO et al., 1986 ; HolOUBeK et al., 1990 ; GALASSI et al., 1993 ; HatFIELD et al., 1996 ; SuzuKI, 1996). Such pesticide concentrations in rainwaters and their ratio of inflow into lakes are still unknown.

The purpose of the present study was to clarify the changes in pesticide concentrations in rainwater during the rainy season, and to determine the ultimate echological impacts of pesticide flux into a lake.

\section{MATERIALS AND METHODS}

The sampling site for rainwater by the National Institute for Environmental Studies (NIES, $140^{\circ} 07^{\prime} \mathrm{E}, 36^{\circ} 02^{\prime} \mathrm{N}$ ) is located in the eastern part of the Kanto Plain about $50 \mathrm{~km}$ northeast of Tokyo (Fig. 1). Rainwater was collected during June and July 1990 . Lake Nakanuma ( $140^{\circ} 09^{\prime} \mathrm{E}, 35^{\circ} 53^{\prime} \mathrm{N}$ ) is located $18.2 \mathrm{~km}$ south of the NIES in Ibaraki Prefecture, Japan. The lake is the deepest $(13.0 \mathrm{~m})$ in the Kanto Plain, and is elliptical in shape with an area of $10,750 \mathrm{~m}^{2}$. According to the topographical map (NI-54-19-13-2) made on a scale of $1: 25,000$ by the Geographical Survey, land use around the lake $(6 \times 6 \mathrm{~km})$ is classified as paddy field $(69.0 \%)$, town $(17.5 \%)$, grassland $(5.1 \%)$, open water $(3.3 \%)$, farmland $(3.1 \%)$, and forest $(2.0 \%)$. The water of one irrigation canal connected with the Kokai River enters the lake. The irrigation water was collected at a site nearest to the lake. Lake water was collected at depth intervals of $2 \mathrm{~m}$ in the center of Lake Nakanuma. Both collections once a week from May to July 1990, and once a month from March to April and from August to December 1990. Daily rainfall data at the Tateno Station, located $0.5 \mathrm{~km}$ east of NIES, were obtained from the Mito Local Meteorological Observatory. Following every steady rainfall, rainwater for pesticide analysis was collected in a stainless steel 10-liter container, stored in a refrigerator, using a stainless steel sink $(47 \times 55 \mathrm{~cm})$ and polytetrafluorethylene tube, and brought back to the laboratory the next day. The water samples were filtered through precombusted $\left(450{ }^{\circ} \mathrm{C}, 3 \mathrm{~h}\right)$ Whatman $\mathrm{GF} / \mathrm{C}$ glass fiber filters to remove suspended matter.

The filtered water was passed through an ODS-packed column (BondElute C18, Analytichem International, U.S.A.) with an aspirator at a rate of about $20 \mathrm{ml} \mathrm{min}^{-1}$ to absorb any pesticides present. The column was then centrifuged once at $3,000 \mathrm{rpm}$ for $20 \mathrm{~min}$ to remove the water, and twice at $1,000 \mathrm{rpm}$ for $15 \mathrm{~min}$ with $0.5 \mathrm{ml}$ acetone to extract the absorbed pesticides. The extract was finally brought to a level of $1 \mathrm{ml}$ with $50 \mu \mathrm{l}$ azobenzene and triphenyl phosphate as internal standards $\left(0.1 \mathrm{mg} \mathrm{l}^{-1}\right)$.

The pesticide concentration was determined with a gas chromatograph (Model 5980A, Hewlett Packard, U.S.A.) fitted with a capillary column (SPB-5, fused silica $0.25 \mu \mathrm{m}, 0.32 \mathrm{~mm}$ inner diameter $\times 30 \mathrm{~m}$ long) and 

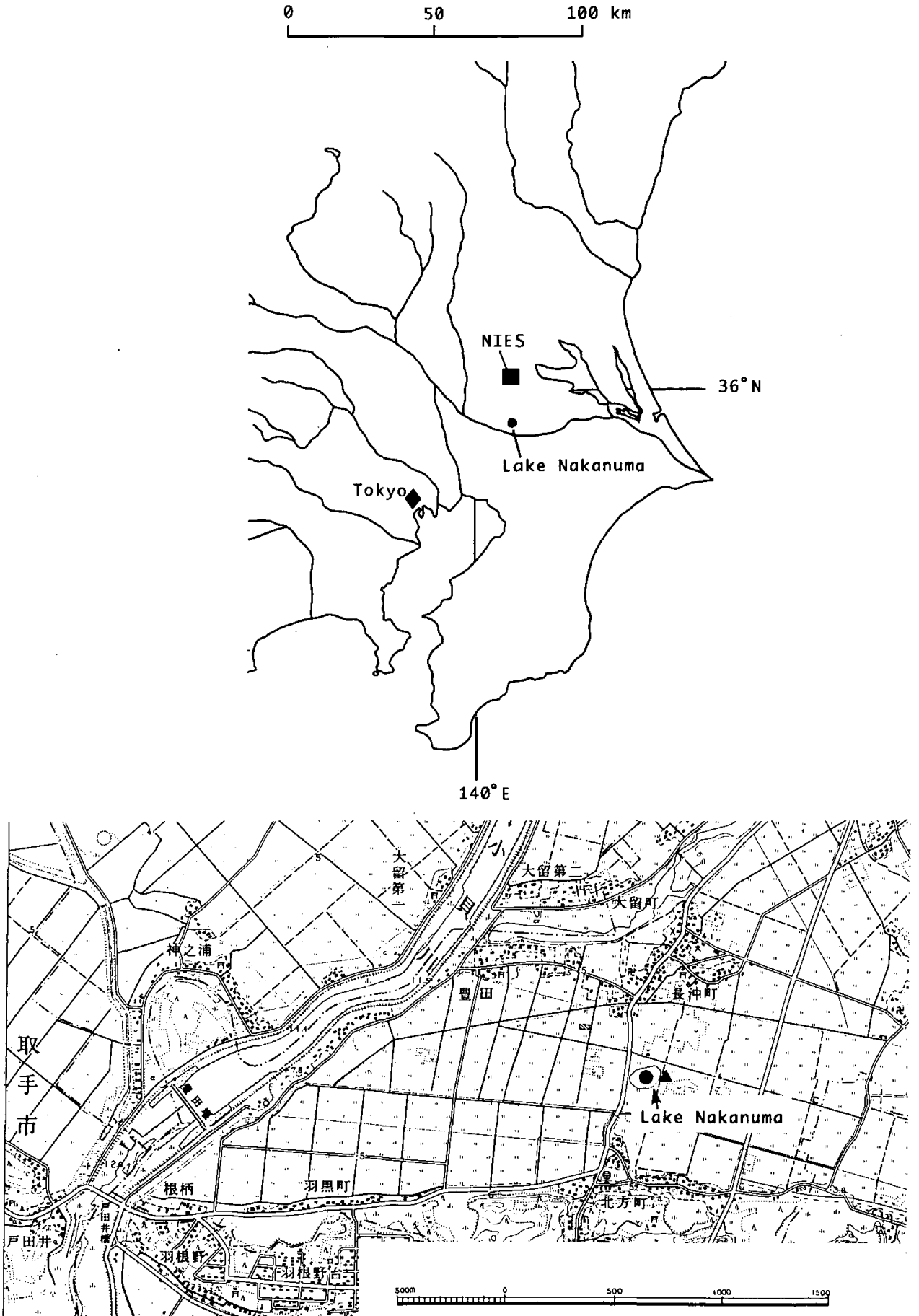

Fig. 1. Map of sampling locations, lakes and major rivers in central Japan. Solid square: rainwater sampling site of National Institute for Environmental Studies (NIES) ; solid circle : lake water sampling site of Lake Nakanuma ; solid triangle : sampling site of irrigation canal into Lake Nakanuma. 
equipped with an autoinjector (Model 7673A, Hewlett Packard, U.S.A.). The peak area of the pesticide signal on the gas chromatogram was determined with a chromatographic data processor (Model 3396, Hewlett Packard, U.S.A.). A nitrogen-phosphorus detector gas chromatograph (GC/ NPD) was used for the determination of fenitrothion (MEP), fenthion (MPP), diazinon, fenobucarb (BPMC), molinate, simetryn, malathion, thiobencarb, butachlor, oxadiazon, chlonitrofen (CNP), edifenphos (EDDP) and iprobenfos (IBP). The column was heated gradually from 50 to $300{ }^{\circ} \mathrm{C}$ with an injector temperature of $250^{\circ} \mathrm{C}$ and a detector temperature of $300{ }^{\circ} \mathrm{C}$.

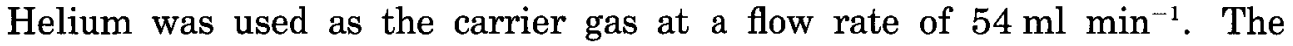
detection limits were $0.02 \mu \mathrm{g} \mathrm{l}^{-1}$ for water.

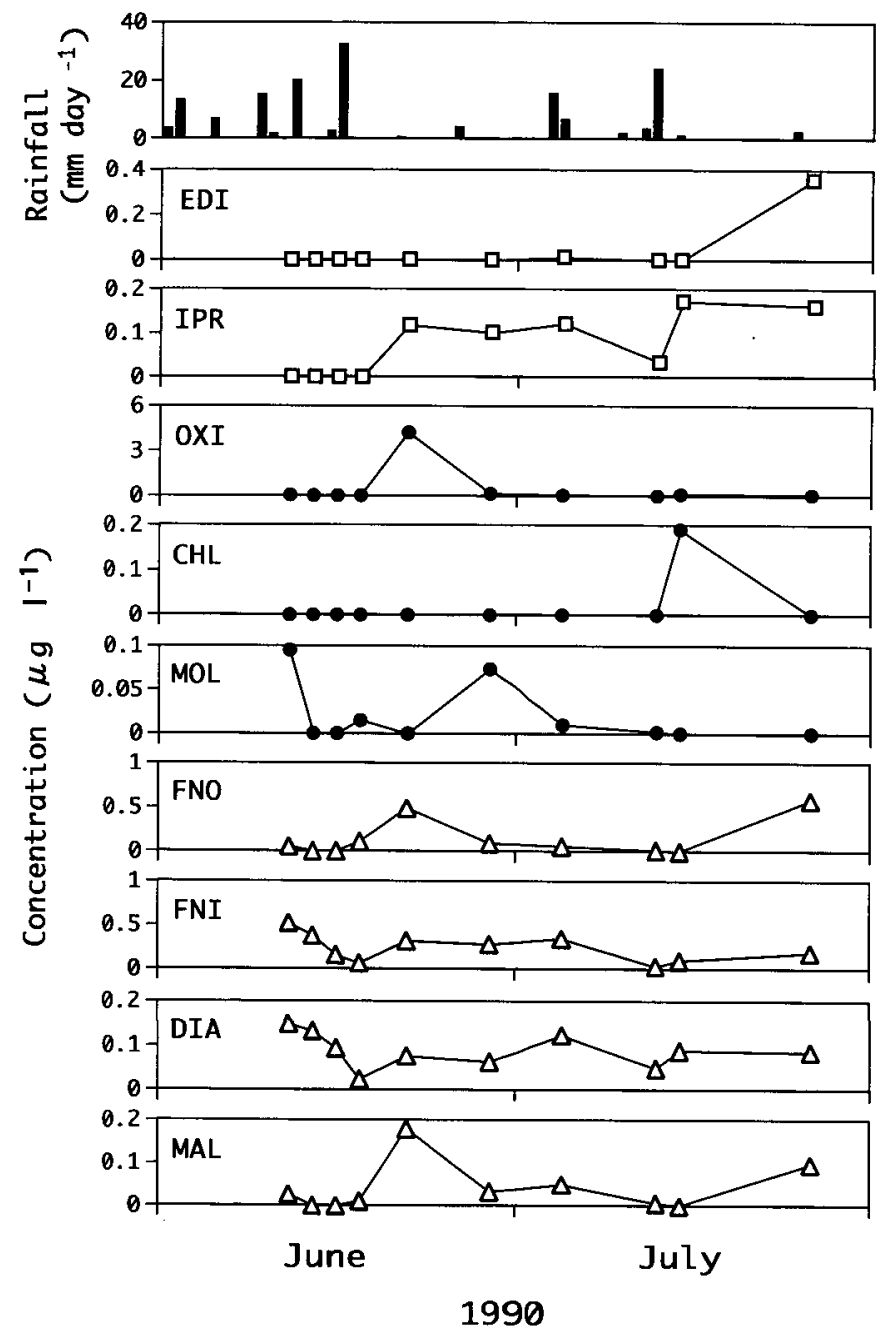

Fig 2. Changes in rainfall and concentrations of major pesticides in rainwater, June and July 1990. Open square : fungicide ; solid circle : herbicide ; open triangle : insecticide. EDI : edifenphos ; IPR : iprobenfos ; OXI : oxiadiazon ; CHL : chlonitrofen ; MOL : molinate ; FNO : fenobucarb ; FNI : fenitrothion; DIA : diazinon ; MAL : malathion. 


\section{RESULTS}

The maximum concentration of edifenphos, a fungicide, in rainwater was $0.36 \mu \mathrm{g} \mathrm{l}^{-1}$ in late July (Fig. 2). The concentration of iprobenfos, a fungicide, was highest $\left(0.17 \mu \mathrm{g}^{-1}\right)$ in July. The concentration of oxadiazon, a herbicide, was highest $\left(4.2 \mu \mathrm{g} \mathrm{l}^{-1}\right)$ of any pesticide in mid-June. The maximum concentrations of chlornitrofen and molinate were 0.19 and 0.10 $\mu \mathrm{g} \mathrm{l}^{-1}$, respectively. Fenobucarb had the highest level $\left(0.58 \mu \mathrm{g} \mathrm{l}^{-1}\right)$ among insecticides. Fenitrothion was detected throught in June and July. Diazinon and malathion had the lowerest levels $\left(<0.2 \mu \mathrm{g} \mathrm{l}^{-1}\right)$ among insecticides. There was no significant difference between each pesticide concentration in rainwater and the amount of continuous rainfall $(\alpha=0.05)$.

Table 1. Water solubility, vapor pressure of pesticide, range of maximum concentration of pesticide and redeposition by rainfall in aquatic ecosystems.

\begin{tabular}{|c|c|c|c|c|c|c|c|c|c|}
\hline \multirow[b]{2}{*}{ Pesticide } & \multirow[b]{2}{*}{$\begin{array}{l}\text { Water } \\
\text { solubil- } \\
\text { ity }^{1)} \\
\left(\mathrm{mg} \mathrm{l}^{-1}\right) \\
\end{array}$} & \multirow[b]{2}{*}{$\begin{array}{l}\text { Vapor } \\
\text { pressure }^{1)} \\
(\mathrm{mPa})\end{array}$} & \multirow[b]{2}{*}{$\begin{array}{l}\text { Shipping } \\
\text { amount } \\
\text { (Ibaraki) } \\
\text { (t) }\end{array}$} & \multicolumn{5}{|c|}{ Range of maximum concentration $\left(\mu \mathrm{g} \mathrm{l}^{-1}\right)$} & \multirow[b]{2}{*}{$\begin{array}{c}\text { Redeposition } \\
\text { by rainfall } \\
\left(\mu \mathrm{gm}^{-2}\right. \\
\left.\text { month }^{-1}\right)^{10}\end{array}$} \\
\hline & & & & $\underset{33,4), 5), 6\}}{\text { River }}$ & $\begin{array}{l}\text { Lake } \\
\text { Kasumi- } \\
\text { gaura } \\
\underset{7), 8), 9)}{ }\end{array}$ & $\begin{array}{l}\text { Lake } \\
\text { Naka- } \\
\text { numa }^{(0)}\end{array}$ & $\begin{array}{l}\text { Irrigation } \\
\text { canal }^{10)}\end{array}$ & Rain $^{10)}$ & \\
\hline Molinate & 880 & 746 & 39.1 & $1.2-23$ & 0.5 & 0.67 & 4.96 & 0.10 & 1.32 \\
\hline Fenobucarb & 660 & 47 & 21.5 & $18-30$ & $1.0-1.6$ & 0.13 & 0.34 & 0.58 & 4.05 \\
\hline Simetryn & 450 & 0.1 & 14.8 & $2.9-11$ & $1.1-4.8$ & 0.91 & 3.51 & ND & 0.00 \\
\hline Iprobenfos & 430 & 0.30 & 59.7 & $3.2-18$ & $3.4-24$ & 0.66 & 2.52 & 0.17 & 2.34 \\
\hline Malathion & 145 & 5.3 & 10.5 & & 0.18 & 0.07 & 0.36 & 0.1 & 1.29 \\
\hline Diazinon & 40 & 0.097 & 34.4 & $0.2-1.0$ & $0.1-0.8$ & 0.03 & 0.11 & 0.15 & 5.47 \\
\hline Thiobencarb & 30 & 2200 & 44.9 & & & 0.17 & 1.20 & 0.07 & 1.31 \\
\hline Butachlor & 23 & 0.6 & 17.2 & $1.5-9.0$ & 0.05 & 0.45 & 0.79 & 0.02 & 0.23 \\
\hline Fenitrothion & 21 & 0.15 & 41.6 & $0.2-20$ & & 0.05 & 0.04 & 0.53 & 14.7 \\
\hline Fenthion & 2 & 4 & 50.0 & $2.6^{-2.8}$ & 1.9 & 0.00 & 0.02 & 0.12 & 1.18 \\
\hline Oxiadiazon & 0.7 & $<0.13$ & 10.2 & $1.1-3.1$ & 0.66 & 0.06 & 0.21 & 4.23 & 2.99 \\
\hline Chlonitrofen & 0.25 & 3.2 & 29.3 & $0.6-4.1$ & & 0.63 & 0.31 & 0.19 & 0.10 \\
\hline Edifenphos & insol. & no data & 12.1 & & 0.36 & ND & ND & 0.36 & 0.56 \\
\hline
\end{tabular}

1) Worthing and Hance, 1991; 2) Agricultural Production Bureau, 1990 ; 3) Nakamura and Osaki, 1984 ; 4) Hatakeyama et al., 1992 ; 5) Numabe et al., 1992 ; 6) Iwakuma et al., 1993 ; 7) Shirai. shi et al., $1988 ; 8,9)$ Nohara and Iwakuma, 1996a,b 10) present study

Concentrations of molinate, simetryn, iprobenfos and thiobencarb in irrigation canal water were in the high range $\left(>1.0 \mu \mathrm{g} \mathrm{l}^{-1}\right.$, Table 1). Those pesticides had high solubility in water $\left(30-880 \mathrm{mg} \mathrm{l}^{-1}\right)$. The maximum concentration of any pesticide (except for chlonitrofen) in the lake $(<1.0 \mu \mathrm{g}$ $\mathrm{l}^{-1}$ ) was lower than any found in irrigation canal water. The maximum concentrations of fenobucarb, diazinon, fenitrothion, fenthion, oxiadiazon and edifenphos in rainwater were higher than tiny in the water of irrigation canals. The maximum concentration of simetryn in Lake Nakanuma was $0.91 \mu \mathrm{g} \mathrm{l^{-1 }}$. Simetryn was not detected in rainwater. The total shipping amounts of 13 pesticides detected in Ibaraki Prefecture $\left(6,094 \mathrm{~km}^{2}\right.$ area) in 1990 was about 385 tons. There was no significant difference between the redeposition amount of each pesticide by rainfall and the shipping amount in 
Ibaraki Prefecture $(\alpha=0.05)$.

\section{DISCUSSION}

The annual redepositions of pesticides by rainfall are $0.11^{-8.1} \mu \mathrm{g} \mathrm{m}^{-2}$ year ${ }^{-1}\left(0.01-1.0 \mu \mathrm{g} \mathrm{m}^{-2}\right.$ month $\left.^{-1}\right)$ in Nara Prefecture (UNo et al., 1986). Their study found iprobenfos, fenitrothion, diazinon, malathion, methidathion, and cyanophos in preserved rainwater during one month. In the present study, the redepositions of pesticides by rainfall during two months was in the high range of as $0.10-14.7 \mu \mathrm{g} \mathrm{m}^{-2}$ month $^{-1}$ (Table 1). The flux of redeposition to the entire prefecture by rainfall was $35 \mu \mathrm{g} \mathrm{m}^{-2}$ month $^{-1}$ $\left(0.25 \mathrm{mg} \mathrm{m}^{-2}\right.$ year $^{-1}$, from April to October). Pesticides with higher vapor pressure and lower solubility in water show higher volatility (YukImoto et al., 1979). Fenitrothion also shows both high vapor pressure and low solubility in water (Table 1). It is worth rioting that high levels of fenitrothion are used for aerial spraying over pine forest around the present study area (Agricultural Production Bureau, 1990 ; Hatakeyama et al., 1990). Therefore, redeposition of fenitrothion by rainfall seemed to be higher than for other pesticides. Based on the mean data of redeposition (Table 1), the redeposition ratio of fenitrothion by rainfall was an estimated $1.5 \%$ of the total shipping amount in Ibaraki Prefecture. That ratio was higher than that of 13 other pesticides $(0.4 \%)$. Fenitrothion is also the most frequently detected pesticide in rainwater in Hyogo Prefecture (FUJIMORI et al., 1994).

In the last ten years, there have been many studies which involved the monitoring of pesticides in aquatic ecosystems in Japan (FukUshima, 1991 ; NUMABE et al., 1992 ; IWAKUMA et al., 1993 ; SHIRAISHI et al., 1988 ; NOHARA and IWAKUMA, 1996a, b). Such monitoring has been restricted to rivers and lakes. The maximum concentration of pesticides except for chlornitrofen in Lake Nakanuma $\left(<1.0 \mu \mathrm{g} \mathrm{I}^{-1}\right)$ was about one-tenth that of the irrigation canal. The amount of pesticide from rainwater was a major factor in estimating the eventual ecological viability of Lake Nakanuma (Table 1). Therefore, the results of the present study suggested the environmental necessity of monitoring the flux of pesticide residues in rainwater into lake ecosystems.

Pesticides can exist in the atmosphere absorbed in soil particles, and can later be redeposited by rainfall on land remote from the site of the original deposition (VISWESWARIAH et al., 1975). They can also enter the atmosphere by volatilization. The falling amounts of pesticides are not clearly related to the retectural shipment amounts (SUzUKI, 1996). In the present study, there was no significant difference between the redeposition amount of each pesticide by rainfall and the shipping amount in Ibaraki Prefecture. Pesticide residues in rainwater are detected only around application areas, and few pesticides are diffused widely in the air (SuzukI, 1996). This makes it difficult to estimate the origin of the pesticides in rainwater. The question of origin aside, in Japan there seems to be no area without pesticide residues in its rainwater. We need many more monitoring sites in Japan for the 
study of pesticide residues in rainwater and their long-term ecological impact.

\section{ACKNOWLEDGMENT}

We thank Dr. H. SHIRAISHI of the National Institute for Environmental Studies (NIES) for providing pesticide identification by gas chromatography. This paper is dedicated to Prof. Isao Ikusima, Chiba University, in honor of his fruitful career in the ecology of aquatic macrophytes.

\section{REFERENCES}

Agricultural Production Bureau (1990) : An Outline of Pesticides., 692pp. Japan Plant Protection Association (in Japanese).

Fujimori, K., Y. Takaishi, T. Nakano and H. Umeda (1994) : Monitoring of pesticides at a golf course. J. Environ. Chem. 4:550-551 (in Japanese).

Fushiwaki, Y., T. Hamamura, A. Hasegawa, K. Urano (1993) : Environmental pollution by pesticides from golf courses in Kanagawa Prefecture. Jpn. J. Toxicol. Environ. Health 39 : 543-548 (in Japanese).

Fukushima, M. (1991) : Fate and behavior of pesticide in aquatic environment. -Case study of Yodo River Basin-. Jpn. J. Water Pollu. Res. 14 : 11-15 (in Japanese).

GaLassi, S., E. Gosso and G. TARTARI (1993) : PCBs and chlorinated pesticides in rains of Northern Italy. Chemosphere $27: 2287-2293$.

Grover, R. (1974) : Herbicide entry into the atmospheric environment. Chem. Can., $26: 36-38$.

Hatakeyama, S., H. Shiraishi and N. KobaYashi (1990) : Effects of aerial spraying of insectcides on nontarget macrobenthos in a moutain stream. Toxicol. Environ. Safety $19: 254-270$.

Hatakeyama, S., H. Shiraishi, A. Hamada (1991) : Seasonal variation of pesticide toxicity bioassayed using a freshwater shrimp (Paratya compressa improvisa) in water collected from rivers of the Lake Kasumigaura Water system. Jpn. J. Water Pollu. Res. 14: 460-468 (in Japanese with English summary).

Hatfield, J. L., C. K. Wesley, J. H. Prueger and R. L. Pfeiffer (1996) : Herbicide and nitrate distribution in Cental Iowa rainfall. J. Environ. Qual. $25: 259-264$.

HaYakawa, S., T. OKuda and S. Tsukada (1996) : The basic study on volatilization of pesticide from water or soil sample. Mie-ken Kankyo Kagaku Senta Kenkyu Hokoku, $16: 85-92$ (in Japanese).

Holoubek, I., L. Houskova and Z. Seda (1990) : Project TOCOEN. The fate of selected organic pollutants in the environment. II Air and rainwater 1988. Toxicol. Environ. Chem. 29 : 19-27.

Imanaka, M., S. Hino, K. Masunaga and T. Ishida (1985) : Oxiadiazon residues in surface water and crucian carp (Carassius cuvieri) of Lake Kojima. J. Pesticide Sci. $10: 125-134$.

Iwakuma, T., H. Shiraishi, S. Nohara and K. Takamura (1993) : Runoff prop- 
erties and change in concentrations of agricultural pesticides in a river system during a rice cultivation period. Chemosphere $27: 677-691$.

MARU, S. (1985) : Monitoring survey of pesticides in river water within Chiba Prefecture. Seitaikagaku $8: 3-10$ (in Japanese).

Nohara, S. and Iwakuma, T. (1996a) : Pesticide residues in water and an aquatic plant, Nelumbo nucifera, in a river mouth at Lake Kasumigaura, Japan. Chemosphere 33 : 1409-1416.

Nohara, S. and Iwakuma, T. (1996b) : Residual pesticide and their toxicity to freshwater shrimp in the littoral and pelagic zones of Lake Kasumigaura, Japan. Chemosphere $33: 1417-1424$.

Numabe, A., T. Inoue and S. EbIse (1992) : Estimation on the runoff amounts of pesticides applied after transplanting of rice plants by drainage river. J. Jpn. Soc. Water Environ. $15: 662-671$.

Okumura, T. (1991) : Volatilization rates of pesticides. J. Environ. Chem. $1: 38$ -47 (in Japanese).

Shiraishi, H., F. Pula, A. Otsuki and T. Iwakuma (1988) : Behaviour of pesticide in Lake Kasumigaura, Japan. Sci. Total Environ. $72: 29-42$.

SuzukI, M. (1982) : Pollution by pesticides of aquatic environment in Kitakyushu district. Seitaikagaku $4: 3-10$.

SuzukI, S. (1996) : Several pesticide residues in rainwater in Eastern Japan, 1989-1992. J. Pesticide Sci., $21:$ 7-15.

Takamura, K., S. Nohara, T. KariYa, M. Okazaki and K. Ito (1991) : Effects of pesticide contamination from rice fields on stream benthic arthropods. Jpn. J. Limnol. $52:$ 95-103.

Tarrant, K. R. and TAtTon, J. O'G. (1968): Organochlorine pesticides in rainwater in the British Isles. Nature, 219 (5155) : 725-727.

Uno, M., Y. OnJI, H. NAgami and Y. Ueda (1986) : Studies on pesticide resudues in rainwater. J. Environ. Labo. Association $11: 23-26$ (in Japanese).

Visweswariah, K., M. Jayaram, S. K. MaJUmder (1975) : Environmental pollution with pesticides. J. Food Sci. Technol. 12 : 53-60.

Yukimoto, M., T. Kaweahara and T. Nakahara (1979): Evaporation of several herbicides from the aqueous solutions. J. Pesticide Sci. 4: 447-451 (in Japanese) .

Seiichi NoHaRa : Environmental Biology Division, National Institute for Environmental Studies, Tsukuba, Ibaraki 305, Japan（野原精一：テ 305 つくば市小 野川 16-2, 国立環境研究所生物圈環境部)

Takayuki Hanazato : Regional Environmental Division, National Institute for Environmental Studies, Tsukuba, Ibaraki 305, Japan ; Present address, Suwa Hydrobiological Station, Shinshu University, Suwa, Nagano 392, Japan (花 里孝幸：干 305 つ〈ば市小野川 16-2, 国立環境研究所地域環境研究グループ; 現住所：T 392 諏訪市湖岸通り5-2-1, 信州大学理学部附属諏訪臨湖害験所)

Toshio Iwakuma : Environmental Biology Division, National Institute for Environmental Studies, Tsukuba, Ibaraki 305, Japan ; Present address, Hokkaido University, Sapporo, Hokkaido 060, Japan（岩熊敏夫：テ305つくば市小野 川 16-2, 国立環境研究所生物圈環境部; 現住所：T 060 札幌市北区北 10 条西 5 丁目, 北海道大学大学院地球環境科学研究科) 


\title{
茨城県中沼の湖水と梅雨期の降水中の農薬残留濃度
}

\author{
野原精一・花里孝幸・岩熊敏夫
}

摘 要

湖への農薬の負荷量を把握するために, 1990 年の梅雨期の雨水中の農薬濃度を荻城䜌で

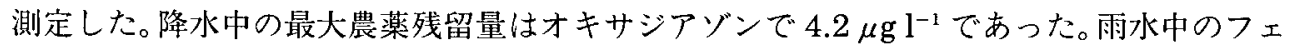
/ベンカーブ(BPMC)，フェニトロチオン(MEP)，エジフェンフォス(EDDP)の濃度は $0.58,0.53,0.36 \mu \mathrm{g} \mathrm{l}^{-1}$ 以下であった。フェニトロチオンの雨水からの年間降下量の割合は 出荷量の $1.5 \%$ と見積もられた。雨水による各農薬降下量は雨量や茨城県の農薬出荷量と の有為な関係は見られなかった。1990 年 3 月から 12 月に茨城県中沼の湖水及び一時的に 流入する農業用水の中の農薬濃度を測定した。モリネート，シメトリン，イプロベンフォ ス (IBP), チオベンカーブの農業用水の中濃度は $1.2 \mu \mathrm{g} \mathrm{l}^{-1}$ 以上と高い範囲にあった。多 アジノン, マラソン, フェンチオン (MPP)の農業用水の中濃度は $0.2 \mu \mathrm{g} \mathrm{l}^{-1}$ 以下と低い範囲 にあった。湖水中のシメトリンの最大濃度は $0.91 \mu \mathrm{g} \mathrm{l}^{-1}$ であった。クロルニトルフェン (CNP) を除いて, 湖水中の最大の濃度は農業用水の約 $1 / 10$ 程度であった。湖沼への農薬流 入を見積もる上で雨水を介しての流入は重要な流入源の一つである事が明らかになった。 